IRA-International Journal of Education \& Multidisciplinary Studies

ISSN 2455-2526; Vol.03, Issue 03 (2016)

Institute of Research Advances

http://research-advances.org/index.php/IJEMS

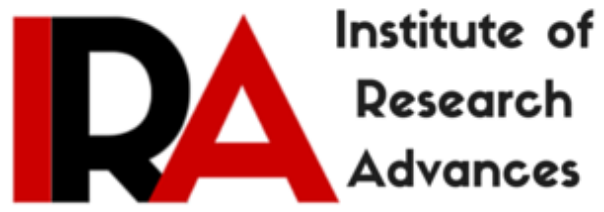

\title{
Awareness and Academic Accommodations Provided by Teachers to Students At-Risk
}

\author{
Ma. Agnes H. Callanta \\ West Visayas State University-Janiuay Campus \\ Cabesa Jose D. Brana Street \\ Janiuay, Iloilo, Philippines.

\section{Guiller P. Pendon} \\ West Visayas State University-Janiuay Campus \\ Cabesa Jose D. Brana Street \\ Janiuay, Iloilo, Philippines.
}

DOI: http://dx.doi.org/10.21013/jems.v3.n3.p14

How to cite this paper:

H. Callanta, M., \& P. Pendon, G. (2016). Awareness and Academic Accommodations Provided by Teachers to Students At-Risk. IRA International Journal of Education and Multidisciplinary Studies (ISSN 2455-2526), 3(3). doi:http://dx.doi.org/10.21013/jems.v3.n3.p14

(C) Institute of Research Advances

\section{(cc) BY-NC}

This works is licensed under a Creative Commons Attribution-Non Commercial 4.0 International License subject to proper citation to the publication source of the work.

Disclaimer: The scholarly papers as reviewed and published by the Institute of Research Advances (IRA) are the views and opinions of their respective authors and are not the views or opinions of the IRA. The IRA disclaims of any harm or loss caused due to the published content to any party. 


\section{ABSTRACT}

The pervasive problem that the Philippine education faces today is teaching students whose attempts at learning result in failure and eventually dropping out of school. This study attempted to identify students at-risk so that teachers may understand their needs and support them. This descriptive research determined the level of awareness of teachers of West Visayas State University-Janiuay Campus, Iloilo regarding students at-risk and their academic accommodation. This study attempted to determine whether the level of awareness of teachers regarding student atrisk affects their accommodation practices they provide. The respondents of the study were the twenty four (24) first year advisers selected through total enumeration of the population. The study showed that when taken as an entire group and when grouped according to various categories, teachers' level of awareness of student at-risk was fairly aware. Only teachers who master's degree holders were very aware and with master's units were less aware. On the other hand, the level of awareness of teachers on academic accommodation of students at-risk were consistently very aware when taken as an entire group and when grouped according to various categories. Only male teachers and teachers of the schools of Hotel and Services Technology and Industrial Technology were extremely aware.

Generally, the most frequently used accommodation practices of teachers while dealing with students at-risk was management followed by assessment and instruction. Another topic featured in the literature includes discussion of the risk factors that act as antecedents to at-risk and the legal foundation of the study.
\end{abstract}

Keywords: awareness, academic accommodation, students at-risk

In 1985, the United Nations (UN) declared the year as the International Youth Year. This led to the benchmark reforms in global and national policies for the welfare and other concerns for the youth. It is undeniable that the youth populace play an important role in the quest for peace and progress. They are important in the economic development of the country.

According to Dobizl (2002) the at-risk problem with our youth has become a nationwide problem that "has social and economic implications for individuals and for society." Gloria LadsonBillings in her speech, claimed that dropout statistics and test scores clearly show academic failure to be one of the greatest problems in education. Teachers on the other hand struggle to maintain classroom discipline with the presence of the apathetic, defiant and disruptive and truant students. Previous studies have shown that teachers lack the knowledge and understanding of the true cause of the disruptive behavior and the individual needs of learners (Neri, 2007).

Hence, the special education standards of the National Council for Accreditation of Teacher Education (NCATE) in its attempt requires professional education programs to prepare all future teachers to contribute to the education of exceptional learners (Turner, 2003). This has become a significant issue for teachers to teach the students at- risk with special needs in an inclusive setting.

This study examines the level of awareness on academic accommodation of students at-risk from the perspective of social cognitive theory of Albert Bandura. This study will help teachers of

Funded by: West Visayas State University-Janiuay Campus 
the West Visayas State University-Janiuay Campus to understand the implications of at-risk and to identify individual needs. As part of the academe, our role is to save them from dropping out from school by providing them appropriate and effective accommodation.

The discussion revolved around the premise that all individuals with disabilities and at-risk have the right to equal opportunity to quality education and should receive accommodation and other educational support. At-risk students are referred to those who have been labeled to be in danger of academic failure. A student can be deemed at risk due to several factors including low test scores, poor attendance, discipline issues, structure at home, socioeconomic status, and others. Most schools have programs such as Title I program (associated Part A of the No Child Left behind Act of 2001) that provide more attention to the students and are designed to keep them from falling through the cracks (Meador, 2012).

General Colin Powell made the following statement at a Philadelphia convention when George W. Bush was nominated as a candidate for President of the United States. Powell said that we have to get back to the business of building children the way we know how, and it is time to stop building jails in America.

The country's effort to increase our literacy rate and decrease dropout rate is anchored from the two provisions of the 1987 Philippine Constitution. Article II, Section 17 provides that the state must give priority to education, while Article XIV, Section 1 guarantees that this education be accessible to all. Hence, appropriate steps must be taken like the creation of Philippine Action Plan (1990-2000). The same way, provisions in IDEA 2004 allow schools to provide early intervening services to students who are considered "at risk." At-risk students are those who show a need for additional academic or behavioral support to succeed in general education, but who are not identified as needing special education (Cortiella, 2003).

A legitimate concern exists today, whether teachers' level of awareness of students at-risk are developing the skills of the teachers necessary to adapt classroom strategies and utilize these to accommodate students at-risk. Accommodation is meant to reduce the impediments of students atrisk in order to save them from experiencing academic failure and leaving school. Furthermore, Cantrell (2000) said that accommodation does not substantially change the instructional level, content nor the performance criteria. The changes are made in order to provide a student equal access to learning and equal opportunity to demonstrate what is known.

Current research indicates that a key to successful accommodation practices lies in teacher level of awareness and extent of understanding the characteristics and needs of student at-risk (Franklin, 2004). In this study, it examines the level of awareness of teachers of West Visayas State University-Janiuay Campus regarding student at-risk and academic accommodation. It includes their creativity and efficacy of their general teaching skills and knowledge in instruction; their skills in assessment to identify students at-risk; their attitudes and classroom management in response to students at-risk.

This study specifically sought answers to the following questions:

1. What is the level of awareness of teachers regarding students at-risk when taken as an entire group and when classified according to sex, educational attainment, length of service and school?

2. What is the level of awareness of teachers on the academic accommodation for students at-risk when taken as an entire group and when classified according to academic sex, educational attainment, length of service and school?

3. What are the most frequently used accommodation practices of teachers while dealing with students at-risk in terms of instruction, management and assessment skills? 
A descriptive research was used in this study. Descriptive research involved collection of data in order to test hypotheses or to answer questions concerning the current status of the subject of the study (Gay, 2000.)

This study ascertained the level of awareness of teachers regarding student at-risk and level of awareness on the academic accommodation as a whole and when they were classified according to sex, academic rank, length of service and school/department. This study also determined the frequently used accommodation strategies and practices of teachers in the university.

As the initial step, the researcher identified first year students who were duly enrolled for the second semester 2014-2015. Students at-risk were identified based on Grade Point Average (GPA) in their high school Form 137 and those belonged to lower 10\% of the class in the first semester. Screening test was done to determine students at-risk administered by the teacher adviser. The teachers were also asked to answer a questionnaire checklist on their level of awareness of student at-risk and academic accommodation they provide for students at-risk. Determination of the most frequently accommodation practices provided by teachers was also established, students were made to answer a questionnaire checklist.

The Questionnaires were validated and pilot tested in order to determine the reliability of each item. The study involved the 24 first year advisers for the study on the level of awareness of academic accommodation and students identified at-risk who are duly enrolled for the second semester in West Visayas State University-Janiuay Campus, Janiuay, Iloilo for the school year 2014-2015. The teachers were grouped according to sex, school, length of service and educational attainment. They were identified through total enumeration. And students were selected through purposive sampling to determine the most frequently used accommodation practices provided by teachers.

Table 1

\section{Respondents}

Profile of the Respondents as to Course, Sex and Year Level

\begin{tabular}{lrc}
\hline Categories & $\mathrm{f}$ & $\%$ \\
\hline Sex & 7 & 29.2 \\
Male & 7 & 70.8 \\
Female & & \\
Educational Attainment & 2 & 8.3 \\
With Doctoral Units/Doctoral Degree & 8 & 33.3 \\
With Masters Units & 9 & 20.8 \\
Masters Degree & 5 & 12.5 \\
Bachelors Degree & & 50.0 \\
Length of Service & 3 & 37.5 \\
5 years and below & 12 & \\
6 to 10 yrs & 9 & 20.8 \\
11 and above & & 16.7 \\
School & 5 & 29.2 \\
School of Teacher Education & 4 & \\
School of Information and & &
\end{tabular}


Services Technology

School of Healthcare Services

4

16.7

School of Industrial Technology

4

Entire Group

24

16.7

100

\section{Research Instrument}

The data-gathering of the first instrument used in the study was an awareness questionnairechecklist adapted from Kravets, M (2006) and Mayers, K.A., Wood , J.N., \& Pousson, M (2007) with some modifications after it was reviewed by the panel of experts.

(1) SURVEY QUESTIONS ON THE LEVEL OF AWARENESS OF TEACHERS ON ACADEMIC ACCOMMODATIONS

The instrument consists of two parts. Part One, requires of personal data of the respondents. Part Two is the instrument proper which contains 22 item statements regarding the respondents' level of awareness of academic accommodation which were further classified according to management, assessment and instruction.

There were five levels to be determined, these are unaware, somewhat aware, aware, very aware and extremely aware.

"Unaware" means that the respondents were not familiar on concepts of academic accommodations.

"Somewhat Aware" means that the respondents had very little familiarity on the concepts of academic accommodations.

"Aware" means that the respondents had high familiarity on concepts of academic accommodations.

"Very Aware" means that the respondents had higher familiarity on concepts of academic accommodations.

"Extremely Aware" means that the respondents had the highest familiarity on concepts of academic accommodations

In determining the results an arbitrary scale of 5-point Likert scale was used to determine the level of awareness of the teachers on academic accommodation.

\begin{tabular}{cl}
\hline Scale of Mean & Description \\
\hline $1.00-1.80$ & Unaware \\
$1.81-2.60$ & Less aware \\
$2.61-3.40$ & Fairly aware \\
$3.41-4.20$ & Very aware \\
$4.21=5.00$ & Extremely aware
\end{tabular}

(2) SCREENING FOR STUDENTS AT-RISK

The instrument is not diagnostic of students at-risk. It is divided into two parts. Part One consists of personal data of the respondents. Part two is the instrument proper that contains 30 item statements identifying students at-risk. The items are answerable by Yes or No.

At this time, the 2-point Likert scale was used to determine the level of awareness of the faculty members regarding students at-risk. 


\begin{tabular}{ll}
\hline Scale & Description \\
\hline $1.81-2.00$ & Extremely Aware \\
$1.61-1.80$ & Very Aware \\
$1.41-1.60$ & Fairly Aware \\
$1.21-1.40$ & Less Aware \\
$1.00-1.20$ & Unaware \\
\hline
\end{tabular}

\section{(3) SURVEY ON ACADEMIC ACCOMMODATIONS OF TEACHERS BY THE STUDENTS}

The instrument is divided into two parts. Part One consists of the personal data of the respondents and Part Two contains the instrument proper. The instrument proper contains twenty six (26) item statements that would require respondents to answer accommodation practices frequently used by teachers for students at-risk. Seven (7) items comprise the management part, eight (8) items on the assessment part and eleven (11) items on the instruction part. The items are answerable by Yes or No.

Table 2

\section{Findings}

The Level of Awareness of Faculty Members Regarding Students At-Risk Taken as an Entire Group

\begin{tabular}{llll}
\hline Categories & Mean & SD & Description \\
$\begin{array}{l}\text { Sex } \\
\text { Male }\end{array}$ & 1.5243 & 0.11631 & Fairly Aware \\
$\begin{array}{l}\text { Female } \\
\text { Educational Attainment }\end{array}$ & 1.5494 & 0.15315 & Fairly Aware \\
$\begin{array}{l}\text { With Doctoral units/ } \\
\text { Doctoral Degree }\end{array}$ & 1.4750 & 0.21920 & Fairly Aware \\
$\begin{array}{l}\text { With Master's Units } \\
\text { Masters Degree }\end{array}$ & 1.5700 & & \\
$\begin{array}{l}\text { Bachelors Degree } \\
\text { Length of Service }\end{array}$ & 1.6211 & 0.07111 & Fairly Aware \\
$\begin{array}{l}\text { 5 yrs \& below } \\
\text { 6 to 10 yrs }\end{array}$ & 1.3820 & 0.12283 & Very Aware \\
$\begin{array}{l}\text { 11 \& above } \\
\text { School }\end{array}$ & 1.5367 & 0.11819 & Less Aware \\
Teacher Education & 1.5000 & 0.19553 & Fairly Aware \\
$\begin{array}{l}\text { Information and } \\
\text { Communications Technology }\end{array}$ & 1.6000 & 0.13170 & Fairly Aware \\
$\begin{array}{l}\text { Hotel Restaurant Services } \\
\text { and Technology }\end{array}$ & 1.5957 & 0.13266 & Fairly Aware \\
$\begin{array}{l}\text { Healthcare Services } \\
\text { Industrial Technology }\end{array}$ & 1.4220 & 0.17050 & Fairly Aware \\
Entire Group & 1.5800 & 0.07089 & Fairly Aware \\
& 1,5421 & 0.10309 & Fairly Aware \\
\hline
\end{tabular}


Table 3

Level of Awareness of Faculty Members on the Academic Accommodation of Student

At -Risk Taken as an Entire Group and when Classified According to Sex, Educational Attainment, Length of Service and School

\begin{tabular}{|c|c|c|c|}
\hline & Mean & SD & Description \\
\hline \multicolumn{4}{|l|}{$\overline{S e x}$} \\
\hline \multicolumn{4}{|l|}{ Male } \\
\hline \multirow[t]{2}{*}{ Female } & 4.5329 & 0.39677 & Extremely aware \\
\hline & 4.1441 & 0.53744 & Very Aware \\
\hline \multicolumn{4}{|l|}{ Educational Attainment } \\
\hline With Doctoral units/ & 4.4100 & 0.38184 & Very Aware \\
\hline \multicolumn{4}{|l|}{ Doctoral Degree } \\
\hline With Masters Units & 4.0225 & 0.62048 & Very aware \\
\hline Bachelors degree & 4.5881 & 0.41337 & Extremely aware \\
\hline \multicolumn{4}{|l|}{ Length of Service } \\
\hline 5 yrs \& below & 4.4400 & 0.27495 & Very Aware \\
\hline 6 to $10 \mathrm{yrs}$ & 4.1358 & 0.60978 & Very aware \\
\hline $11 \&$ above & 4.3589 & 0.46150 & Very Aware \\
\hline \multicolumn{4}{|l|}{ School } \\
\hline Teacher Education & 4.1900 & 0.49178 & Very aware \\
\hline Information & 3.9900 & 0.38531 & Very aware \\
\hline \multicolumn{4}{|l|}{ Communications Tech } \\
\hline $\begin{array}{l}\text { Hotel Restaurant Services } \\
\text { and Tech }\end{array}$ & 4.5586 & 0.31778 & Extremely Aware \\
\hline $\begin{array}{l}\text { Bachelor of Caregiving } \\
\text { Management }\end{array}$ & 3.7950 & 0.73993 & Very aware \\
\hline Industrial Technology & 4.5450 & 0.41805 & Extremely Aware \\
\hline Entire Group & 4.2575 & 0.52400 & Very Aware \\
\hline
\end{tabular}


Table 4

Three Most Frequently Used Accommodation Practices of Teachers while Dealing with Students At-risk in Terms of Management

\begin{tabular}{lllc}
\hline Categories & Mean & SD & Rank \\
\hline $\begin{array}{l}\text { Create alternative solutions to problems } \\
\quad \text { through role playing }\end{array}$ & 1.6023 & 0.26761 & 1 \\
$\quad \begin{array}{l}\text { Use peer tutors/cooperative learning } \\
\text { Change location so that students does } \\
\quad \text { not distract others }\end{array}$ & 1.4129 & 0.26757 & 2 \\
\hline
\end{tabular}

Table 5

Three Most Frequently Used Accommodation Practices of Teachers while Dealing with Students At-risk in Terms of Assessment

\begin{tabular}{lccc}
\hline Categories & Mean & SD & Rank \\
\hline $\begin{array}{l}\text { Select correct effective reinforcers in developing } \\
\quad \text { Appropriate behaviors }\end{array}$ & & & \\
Grade on the basis of content, do not penalize & & & \\
$\quad$ For errors in the mechanics and grammar & 1.3767 & 0.31113 & 1 \\
Teach test-taking strategies & 1.2060 & 0.28239 & 2 \\
\hline
\end{tabular}

Table 6

Three Most Frequently Used Accommodation Practices of Teachers while Dealing with Students At-risk in Terms of Instruction

\begin{tabular}{llll}
\hline Categories & Mean & $S D$ & Rank \\
\hline Teach mnemonics as a memory tool & 1.3933 & 0.24538 & 1 \\
Provide definite purpose and expectations & & & 2 \\
$\quad$ Especially during unstructured activities & 1.3127 & 0.24167 & 3 \\
Use concrete examples/models/rubrics & 1.2106 & 0.21115 & 2 \\
\hline
\end{tabular}

\section{Discussion}

The findings of the study of teachers at West Visayas State University- Janiuay Campus, Janiuay, Iloilo showed that teachers were consistently fairly aware in their level of awareness regarding students at-risk when classified according to sex, educational attainment, length of service and school and when taken as an entire group. However, when classified according educational attainment only those who were bachelor's degree holders were less aware in their level of awareness regarding students at-risk, and master's degree holders showed that they were very aware. 
The level of awareness of teachers on academic accommodation of students at-risk when taken as an entire group were very aware. According to sex, male teachers were extremely aware and female teachers were very aware. When classified according to educational attainment and length of service teachers were very aware. According to school, teachers of the Schools of Hotel and Restaurant and Services Technology and Industrial Technology were extremely aware and teachers of Schools of Teacher Education, Healthcare Services and Information and Communications Technology were very aware.

Generally, the most frequently used accommodation practices of teachers while dealing with students at-risk according to areas was management followed by assessment and instruction. These results seemed to support the fact that the most frequently noticeable symptoms of at-risk students were their behaviors which were different from that of their peers. Thus, classroom management was vital part of accommodating students at-risk.

The result shows that the most frequently used accommodation practices of the teachers in the area of Management is creating alternative solutions to problems through role playing followed by Using peer tutors/ cooperative learning.

In terms of Assessment, the result shows the frequently used accommodation practices of teachers is selecting correct effective reinforcers in developing appropriate behaviors followed by grading on the basis of content, do not penalize for errors in mechanics and grammar. On the other hand, having student repeat and explain directions to check for understanding, was the least used.

The data in the most frequently used accommodation practices of the teachers in the area of instruction, teaching mnemonics as a memory tool followed by providing definite purpose and expectations especially during unstructured activities. Giving short and simple directions with examples was the least used.

In an attempt to accommodate students at-risk, teachers often face the ethical dilemma regarding the rights of students against the academic integrity of a course of study. It is the question of where to draw the line in support of providing reasonable academic accommodation for students at-risk which will not jeopardize the standard of the school and disrupt the collegial environment (Birnbaum, 2001). Since student at-risk has a myriad of risk factors, these conditions pose risk leading to academic failure and leave school. When working with students at-risk, the accommodations will often involve academic adjustments in faculty teaching and/or how they evaluate the learning in the course.

The level of awareness of teachers regarding student at-risk and the level of awareness on academic accommodation do not affect their accommodation practices for students at-risk.

The result supports the awareness study of Garcia (2000) were the respondents did not show any difference on their level of awareness with their classroom practices. Further, the study of Tharp (2009) which discussed the awareness level of teachers of students who were in special education and their practices showed significant difference, agreed with the view that one's level of awareness was vital in strengthening the commitment of teachers in their accommodation practices and building relationship and attitude towards them.

However, according to Stafford and Green (2006), teachers' awareness is a vital part in accommodation. It was critical for teacher to be aware in order to have comprehensive planning and implementing a successful inclusion program.

In a similar finding, Yedlin (2004) concluded that teachers who had increased awareness toward children with disabilities affected their experiences with children in the inclusive classroom. The same findings with the studies of Siu Wheelock, (2006) that addressed the factors associated with successful accommodations. 
The diversity of special needs in our schools poses opportunities for all. Accommodations involve many kinds of techniques and support systems. Accommodations help students work with their limitations related to their needs. Accommodations are to make sure that student at-risk can participate as fully as possible in the general curriculum and ultimately earn a diploma. Accommodations can be provided in areas such as instruction, management and assessment.

According to Donnelly 2005, programs are designed in a broad range of special services to help atrisk students improve their low self-esteem in which they can begin to have positive experiences. These programs are remediation, tutoring, child care services, substance abuse awareness programs, bilingual instruction, employment training, and close follow up procedures on truancy and absenteeism. However, there are issues and concerns that need to be discussed regarding accommodating student at-risk.

\section{Conclusions}

The study proved that teachers of the West Visayas State University-Janiuay Campus were consistently fairly aware regarding student at-risk and generally very aware of the academic accommodation of students at-risk with management followed by assessment and instruction as the most frequently used accommodation practices.

The study proved that teachers did not greatly improved their skills in identifying students at-risk. Results of the study point to a need in improving the skills of the teachers in identifying students at-risk to understand their needs. The difficulty in identifying stem from the fact that most students at-risk do not differ from their classmates in terms of their physical appearance and physical stature.

The study proved that the level of awareness of academic accommodation among teachers which was very aware maybe shaped by their underlying belief that students across academic spectrum have the capacity to learn. It reinforced the contention that early in the process of teacher education, teachers had to develop positive professional self-awareness. It must be evident of teachers in order to express a commitment to and belief in the principles of equal and quality education. It is anticipated that this would lead to opening doors to have a closer look as regards to our policies and practices to better accommodate our students in school. This study offers a new perspective on the accommodation practices in the post-secondary education.

It also showed that the least frequently used academic accommodation teachers provide in dealing students at-risk was in the area of instruction. At various times teachers' skills in assessment, management and effective strategies can help at-risk students from dropping out. Hence, it is important for teachers to improve their knowledge and creativity in the delivery of instruction; their capacity to form and sustain interpersonal relationships with students at-risk.

Accommodations and modifications are types of adaptations that are made to the environment, curriculum, instruction, or assessment practices in order for students with diverse educational needs to be successful learners and to actively participate with other students in the general education classroom and in school-wide activities.

Accommodations are changes in how a student accesses information and demonstrates learning. Accommodations do not substantially change the instructional level, content, or performance criteria. The changes are made in order to provide a student with equal access to learning and an equal opportunity to show what he or she knows and can do.

The results of the study shall justify the following recommendations that West Visayas State University-Janiuay Campus must establish a commitment with the intent of accomplishing the following: 
Previous discussions may suggest that teaching strategies should be tailored according to the individual learning needs of student at-risk having the contention that every child has the capacity to succeed in school and in life. The school should develop an early warning system for detection of potential at-risk students thus, provide them early intervention.

Teachers may lack the knowledge and skills in instruction that they need to improve in that area. Moreover, there is a need for family collaboration and involvement in decision making and participation in the learning process of their child.

The administration must provide instructional support, training and giving seminar workshops for teachers. The school must intensify its linkage with local govt. agencies that provides the necessary support for program implementation and financial support to students who belong to low income families like scholarships and other financial aids.

Educators, researchers, and policymakers must continue to work to identify defective unfriendly environment to accommodate students at-risk through revision of the curriculum and policies of the school. To intensify intervention in accommodating student at-risk there is a need to revisit our accommodation policies and programs for student at-risk.

\section{References}

Bimbaum, B.W. (2001). Dimensions of Service Quality: A Study Using Computers to Modify the Curriculum for Students with Learning Disabilities. 5(6): pp. 39-43.

Cortiella, C. (2004). IDEA 2004 Close Up: Disciplining students with disabilities, The Advocacy Institute: Texas, USA.

Dennelly, Bonfiglio, R. (2005). The professionalization of student learning practice: An ethos of scholarship. About Campus.14 (1), 16-20

Director Lolita Andrada of DepEd's Bureau of Secondary Education Communications Unit Office of the Secretary | Department of Education, Pasig City. Website: www.deped.gov.ph Email: commosec@deped.gov.ph

Dobial ,J.W., Cnaan, R.A. and Gelles, R.J. (2012) Adolescent Risk Behaviors and Religion: Findings from Human Exceptionalities Eds.

Franklin, A. M. (2004). Culturally responsive pedagogy for the 1990's and beyond. Washington, DC: ERIC Clearinghouse on Teacher Education

Garcia, A. M. (2000). Culturally responsive pedagogy for the 1990's and beyond. Washington, DC: ERIC Clearinghouse on Teacher Education

Gay, C. (Ed.) (2000). If only I could ...Read write spell: Identifying and helping adults who find learning difficult. Knoxville, TN: Center for Literacy Studies, University of Tennessee, USA.

Kravets, M (2006). Hidden Disabilities: Another diverse population. Journal of College Admission, $190,18-25$.

Ladson-Billings, G. (2006). Educational philosopher claimed in a 2006 convention.

Meador, H., Hubbard, L., \& Villanueva, I. (2012). Forming academic identities: Accommodation without assimilation among involuntary minorities.

Meador, H., Hubbard, L., \& Villanueva, I. (2012). Forming academic identities: Accommodation without assimilation among involuntary minorities.

Myers, K.A., Wood , J.N., \& Pousson, M (2007). Universal instructional design: A community relations plan for K-12 success. Journal of School Public Relations, 28, 251-270.

Neri, N.S. (2007). "Understanding the persons with disabilities with Philippine origin": psychological processes (M. Cole, V. John-Steiner, S. Scribner, \& E. Souberman,

SiuWheelock, S.(2006). College Report No. Asian American students at-risk. A literature review.

Source:Learning Styles and Multiple Intelligence, http//www.1dpride.net

Staford and Green, L. S. (2006). Mind in society: The development of higher 
Tharp, R. G. (2009). Psychocultural variables and constants: Effects on teaching in academic accommodation

Turner, C. (Ed.) (2003). If only I could ...Read write spell: Identifying and helping adults who find learning difficult. Knoxville, TN: Center for Literacy Studies, University of Tennessee, USA.

United Nations Educational, Scientific and Cultural Organization (UNESCO) National Commission of the Philippines. (2004)

United Nations Educational, Scientific and Cultural Organization (UNESCO) National Commission of the Philippines. (2004)

Yedlin, J. (2004, January/February). Teacher talk: Enabling ELLs to "grab on" and climb high. Perspectives. 


\section{SURVEY QUESTIONS ON THE LEVEL OF AWARENESS OF TEACHERS ON ACADEMIC ACCOMMODATIONS}

Personal Data:

Name: (optional)

Sex:

Age:

School:

Length of Service

(5years and Below)

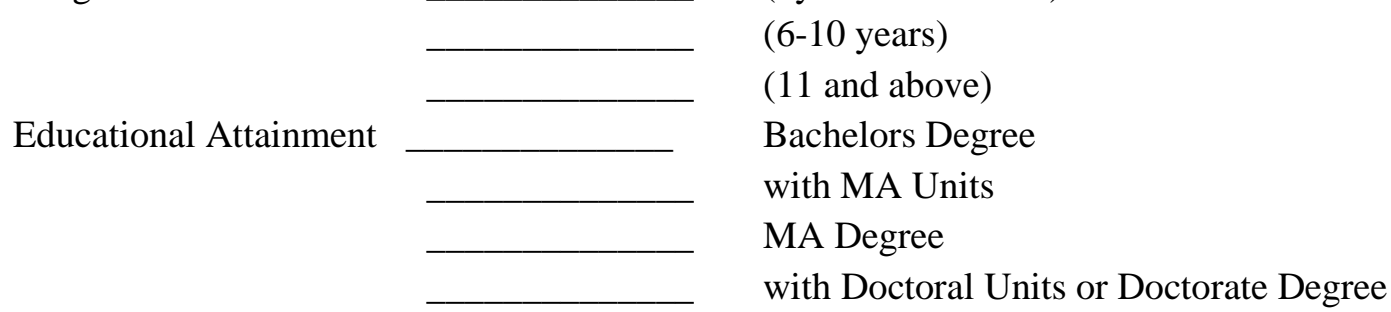

Directions: Please mark $(\sqrt{ })$ on the appropriate space corresponding your responses on the following items using the scale given below:

5 Extremely Aware

$4 \quad$ Very Aware

3 Fairly Aware

2 Less Aware

1 Unaware
The teachers are highly knowledgeable of the academic accommodation.

The teachers are often knowledgeable of the academic accommodation.

The teachers are somewhat knowledgeable of the academic accommodation.

The teachers are less knowledgeable of the academic accommodation.

The teachers have no knowledge of the academic accommodation.

\begin{tabular}{|c|c|c|c|c|c|}
\hline I am aware that... & Unaware & $\begin{array}{c}\text { Less } \\
\text { Aware } \\
2\end{array}$ & $\begin{array}{c}\text { Fairly } \\
\text { Aware } \\
3\end{array}$ & $\begin{array}{c}\text { Highly } \\
\text { Aware } \\
4\end{array}$ & $\begin{array}{c}\text { Extremely } \\
\text { Aware } \\
5\end{array}$ \\
\hline $\begin{array}{c}\text { 1. Dealing with learners who are at-risk entails } \\
\text { empathy, patience, kindness and } \\
\text { understanding. }\end{array}$ & 1 & & & & \\
\hline $\begin{array}{c}\text { 2. Parents should be involved in making decisions } \\
\text { about the progress of their child at-risk. }\end{array}$ & & & & & \\
\hline $\begin{array}{c}\text { 3. Effective academic accommodation and } \\
\text { inclusion can help improve self-esteem and } \\
\text { adaptation. }\end{array}$ & & & & & \\
\hline $\begin{array}{c}\text { 4. Effective accommodation or support service can } \\
\text { decrease rate of dropouts }\end{array}$ & & & & & \\
\hline $\begin{array}{c}\text { 5. Special education is vital part of education } \\
\text { curriculum. }\end{array}$ & & & & \\
\hline $\begin{array}{c}\text { 6. Mainstreaming students will make the life of } \\
\text { students at-risk easier and healthier. }\end{array}$ & & & & \\
\hline
\end{tabular}




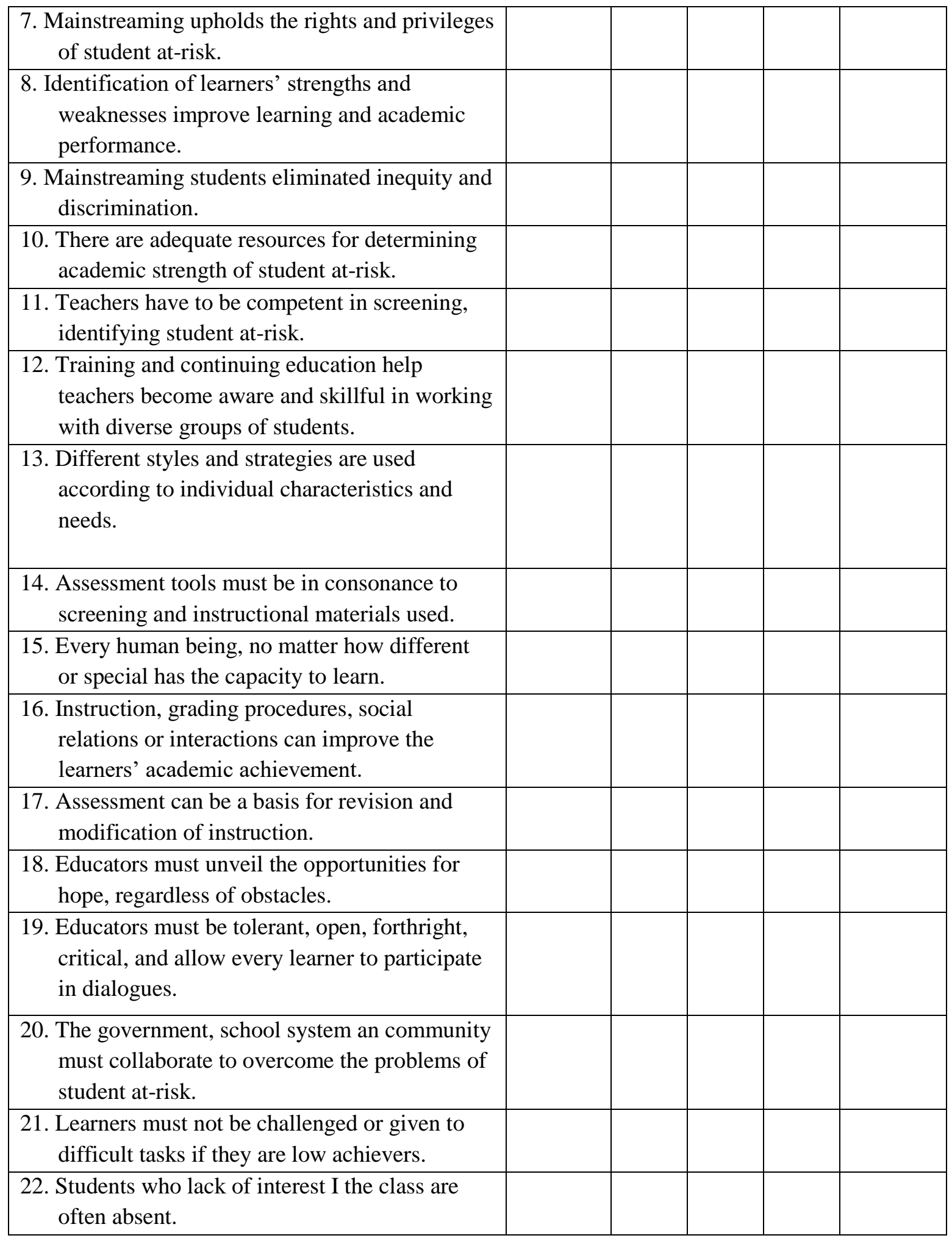

Thank you. 


\section{SCREENING FOR STUDENT AT-RISK}

Personal Data:

Name of student (optional)

Address:

Sex:

Age:

School:

Teacher Adviser:

This survey will be treated with confidentiality, please mark check $(\sqrt{ })$ column Yes if it is applicable and mark check $(\sqrt{ })$ the No column if it is not applicable such that $\mathrm{YES}=1$ and $\mathrm{NO}=0$.

\begin{tabular}{|c|c|c|}
\hline \multirow{2}{*}{$\begin{array}{l}\text { The student... } \\
\text { 1. Cannot use basic phonics to sound out words }\end{array}$} & 1 & 0 \\
\hline & & \\
\hline 2. Substitutes, deletes, adds or transposes letters and syllables & & \\
\hline 3. Often resorts to guessing words when he does not understand & & \\
\hline $\begin{array}{l}\text { 4. Appears re-reading or reads very slowly or reads aloud during } \\
\text { silent reading }\end{array}$ & & \\
\hline 5. Has problems with grammar or syntax & & \\
\hline 6. Misspells words in the same text & & \\
\hline 7. Reveals poor organization in writing & & \\
\hline 8. Inconsistent memory for sentence mechanics & & \\
\hline 9. Manifest common punctuation errors e.g. : for ; , for . & & \\
\hline $\begin{array}{l}\text { 10. Mixes capital and lower case letters inappropriately, } \\
\text { e.g. Sunday, Money }\end{array}$ & & \\
\hline 11. Has poor hand writing and inconsistent in letter formation & & \\
\hline 12. Often does self-talk while writing & & \\
\hline 13. Has trouble remembering Math facts and procedures & & \\
\hline $\begin{array}{l}\text { 14. Demonstrate lack of mastery in addition/ } \\
\text { subtraction/multiplication/division }\end{array}$ & & \\
\hline 15. Has difficulty concentrating/focusing and easily distracted & & \\
\hline 16. Can hardly sits still/ restless/ fidgets & & \\
\hline $\begin{array}{l}\text { 17. Has orientation problems/difficulty: left/right, up/down, and } \\
\text { north/south, east/west or problem with spatial orientation }\end{array}$ & & \\
\hline 18. Has variable or unpredictable behavior & & \\
\hline 19. Absenteeism and tardiness are frequent & & \\
\hline 20. Displays low esteem and self-determination & & \\
\hline 21. Finds it hard to follow directions & & \\
\hline $\begin{array}{l}\text { 22. Has difficulty retaining information without excessive rehearsal } \\
\text { and practice }\end{array}$ & & \\
\hline 23. Often late in activities and shows poor productivity & & \\
\hline $\begin{array}{l}\text { 24. Displays lack of interest in listening and taking part in the } \\
\text { classroom activity }\end{array}$ & & \\
\hline 25. Has difficulty in establishing friendships & & \\
\hline 26. Blurting out; frequent interruptions at inappropriate times or & & \\
\hline
\end{tabular}


IRA-International Journal of Education \& Multidisciplinary Studies

\begin{tabular}{|l|l|l|}
\hline \multicolumn{1}{|c|}{ becomes impulsive } & & \\
\hline 27. Has left school/drop out of school & & \\
\hline 28. Early pregnancy/ early marriage & & \\
\hline 29. Has been working/ financial problems & & \\
\hline 30. Drug/alcohol abuse & & \\
\hline
\end{tabular}




\section{SURVEY ON ACADEMIC ACCOMMODATIONS OF TEACHERS BY THE STUDENTS}

Personal Data:

Name: (optional)

Sex:

Age:

Subject Teacher:

Subject:

School:

Directions: These questions will guide you to identify varied strategies in academic accommodation used by teachers. Please check the item that corresponds to your answer where Yes $=1$ and $\mathrm{NO}=0$

\begin{tabular}{|c|c|c|}
\hline Does your teacher... & 1 & 0 \\
\hline 1. Change location so that a student does not distract others? & & \\
\hline 2. Give short and simple directions with examples? & & \\
\hline 3. Use visual or graphic materials or devices to solve or organize responses? & & \\
\hline 4. Have student repeat and explain directions to check for understanding? & & \\
\hline 5. Allow extra response time for processing? & & \\
\hline $\begin{array}{l}\text { 6. Grade on the basis of content, do not penalize for errors in mechanics and } \\
\text { grammar? }\end{array}$ & & \\
\hline 7. Provide opportunities for movement from topic to another? & & \\
\hline 8. Help the student set and monitor personal goals? & & \\
\hline 9. Use active learning to increase opportunities for student participation? & & \\
\hline 10. Provide opportunities to change tasks or activities more frequently? & & \\
\hline $\begin{array}{l}\text { 11. Provide definite purpose and expectations especially during unstructured } \\
\text { activities? }\end{array}$ & & \\
\hline 12. Use peer tutors/ cooperative learning? & & \\
\hline 13. Provide individual guidance and help? & & \\
\hline 14. Teach vocabulary in context? & & \\
\hline 15. Use frequent repetition of key points? & & \\
\hline 16. Break down instructional units into smaller steps? & & \\
\hline
\end{tabular}




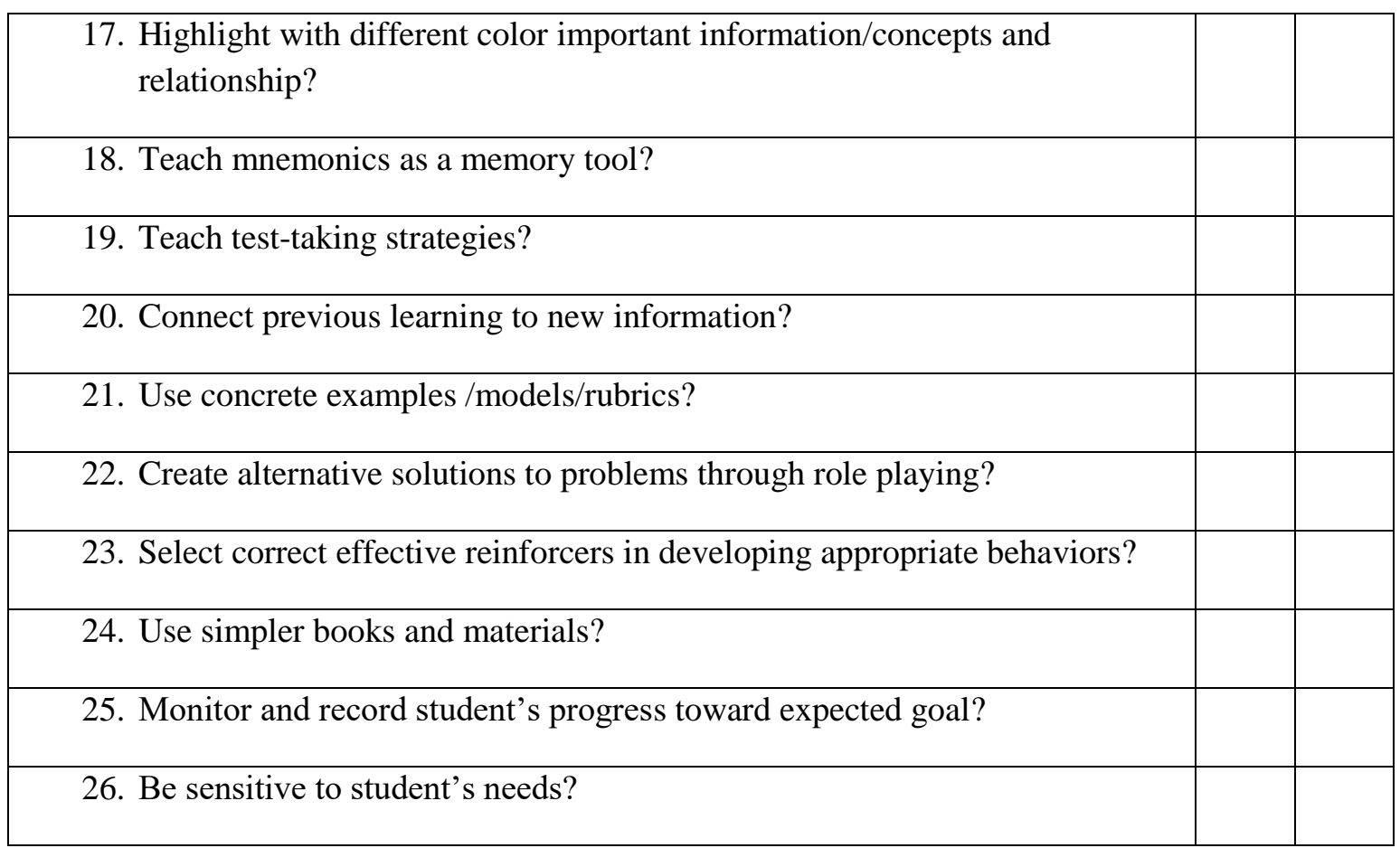

Thank you. 